\title{
Hutchens, Anna: Changing Big Business: The Globalisation of the Fair Trade Movement
}

Edward Elgar, Cheltenham, UK, Northampton, Mass, 2009, $236 \mathrm{pp}$

\author{
William H. Friedland
}

Accepted: 12 January 2010/Published online: 2 February 2010

(C) The Author(s) 2010. This article is published with open access at Springerlink.com

When the pace and scale of food horrors increased in the 1980s and as consumers sought safety in organic foods, a concomitant alternative food movement, Fair Trade, also began to develop. Fair Trade and organics each had international expressions but Fair Trade's globalism was far more profound. Originated by religious groups and civil society organizations such as Oxfam concerned about the huge differences between what Third World indigenous artists received for their work and the prices paid by First World consumers, Fair Trade was created to get a greater proportion of the monetary value of arts and crafts back to their creators.

To accomplish this, a network of small retail shops was organized to sell these artifacts to consumers, eliminating the intermediate levels of collection and distribution that absorbed the bulk of the profits. The shops proved successful but, with limited items for sale, they failed to deal with the enormous discrepancies between prices paid for most Third World commodities and their prices in the First World, bulk commodities such as coffee, tea, cacao, bananas, cotton, etc. The concept of alternative trade organizations (ATOs) emerged as a result. In the Netherlands, the Max Havelaar labeling organization pioneered a campaign to gain access for Fair Trade commodities in Dutch and other European supermarket chains. Similar labeling campaigns were also successfully initiated in the U.S. and a host of other countries.

With expansion into mass bulk commodities, complex international organization became vital. And unlike organics, which grew as increasing numbers of people became concerned about food safety and health, Fair Trade grew on an ethical basis, i.e., to produce better returns to primary producers to help alleviate Third World poverty.

As Fair Trade and organics became successful both movements began to adapt to standard market conditions, a process named conventionalization or mainstreaming.

W. H. Friedland ( $\square)$

University of California, Santa Cruz, CA, USA

e-mail: friedla@ucsc.edu 
Each case, however, was different, Organics, especially in the U.S., turned to the state to establish definitions as to what could legally be labeled organic; Fair Trade, in contrast, formulated its own definitions because it connected southern production to northern consumption. Labeling became the key strategy, a process superintended by a complex of organizations. Conventionalization took the form of increasing the volume of southern products reaching northern consumers. This, in turn, led large transnational corporations to conform to Fair Trade pricing for minor segments of southern commodities in which they traded.

Hutchens's book focuses on the developing crisis within the Fair Trade movement between the licensing organizations, largely preoccupied with expansion of volume, and producer organizations, which saw such licensing as abandoning the original intent of Fair Trade to encompass whole commodity chains and resist the allocation of Fair Trade labels to miniscule percentages of commodities processed and distributed by transnational corporations.

Hutchens's analysis of the growing split is fairly clear. The book, however, suffers from over-theorization and over-referencing to the point that reading requires substantial effort to keep abreast of the complex of actors and organizations. Over-theorization refers to Hutchens's setting out lengthy discussions of different types of power. This emphasized those Fair Trade entrepreneurs making changes while staying within "normal" market guidelines. Other Fair Trade activists took a more expansive view, seeking to limit the influences of standard markets. Over-referencing is characterized by incessant references to the point of confusion; in this respect, the origin of the book as a dissertation has not been overcome.

Hutchens's key analytic issue is: how does agency become manifested among Fair Traders?

Hutchens ties the operationalization of Fair Trade to two strategies: resistance or game-playing. Resisters are entrepreneurs focused on scaling up volume, which results in

...a tendency [toward] market preservation rather than market innovation... roasters still capture the lion's share of the dollar value;... roasters receive 13 times more than individual producers and 22 times as much as the cooperative... [the] system may pay producers a relatively higher price for their coffee... [although] producers' remuneration remains marginal to that systematically accrued by market players who control branding and distribution (p. 119).

Game players are Fair Trade entrepreneurs who refuse to lock themselves into continuing the traditional distribution of value in the economic differentials between South and North. They access knowledge to maintain continuous innovation to bring increasing value to southern producers. Hutchens cites examples such as the U.K. Divine Chocolate Company and AgroFair, which sells bananas and fruit across Europe. Producers have ownership stakes in each company, receiving higher prices for their production and also sharing in company profits.

The typological nomenclature "resisters" and "game-players" had to be overcome with some difficulty by this reviewer. Hutchens characterizes those Fair 
Trade activists satisfied with accepting an increased stable price for producers as resisters; this seemed just as peculiar as characterizing those that moved downstream to production/distribution to capture a larger share of the value as game players. Whatever the names, the different orientations have produced a significant split within the Fair Trade movement. As Fair Trade expanded from arts and crafts to mass bulk commodities, Fair Traders had to come to grips with how should Fair Trade be governed?

Fair Trade at its inception had of necessity avoided the strategy undertaken by organics in the U.S. When organics pioneers began to show signs of coherent organization, the key problem they confronted was how to ensure that the term "organic" had a clear meaning. At that time in the U.S., anyone could label their product "organic" no matter the production practices. Consumers were often suspicious of organic claims since, from the beginning, organic prices were significantly higher than conventional crops. Organic growers turned to the state to establish enforceable definitions. The formal bodies of the state, Congress and the U.S. Department of Agriculture (USDA), initially were disinterested or, in the case of the USDA, hostile.

Congress eventually acted, mandating USDA to establish regulatory criteria defining organics. After long complicated debates and shenanigans, procedures were agreed upon by stakeholders, submitted to USDA, which engineered a major subversion that generated the largest protest feedback USDA had ever experienced. USDA learned its lesson, withdrew its subversion, and proceeded to more covert forms of sabotage, encouraged by large transnational corporations entering organic production to capture price premiums. This put the organics movement firmly on the path to conventionalization.

Fair Trade pioneers, originally focused on indigenous arts and crafts, had conceptualized maintaining complete control of the commodity chain from producer to consumer. There never was a turn to the state to set standards and establish controls; from its inception, Fair Trade was "owned" by organizations created by southern producers and ethically concerned northern activists functioning in civil society.

As the shift began with a new set of activists committed to Fair Trade of mass bulk commodities, a northern organizational structure was put in place (in Europe and the U.S.) that pressured supermarket chains to buy Fair Trade commodities. These organizations worked primarily at the level of consumption to get Fair Traded commodities into shops. Attention was also given to relations with southern producer cooperatives to ensure that better prices would get back to producers. This involved licensing the Fair Trade label.

As Fair Trade commodities successfully penetrated national supermarket chains-Switzerland and Netherlands were the initial successes-the basis was created for North-South organizational tensions. For one thing, the North-South division resembled far too closely traditional North-South colonial history with power concentrated in the North. Further, most northern organizations were focused on increasing volume of commodities bearing the Fair Trade labels; they were willing to allocate the label to transnational corporations interested in licensing small percentages of their commodities. Thus, corporations such as Nestlé and 
Starbucks would agree to buy some small percentage of their commodities bearing the Fair Trade label.

This outraged some southern producers but also some northern organizational pioneers who believed that licensing labels should be limited to buyers willing to shift entirely to Fair Trade commodities. While coffee and cacao are mainly produced by smallholders organized in co-ops, tea is largely produced on plantations (large land-holdings of traditionally rich planters) and when some plantations were licensed with the Fair Trade label, this was opposed by some Fair Trade pioneers.

Governance is the focus of the final substantive chapter of the book. What has emerged is a controlling body representing the northern Fair Traders in consumer nations and a second body composed of northern Fair Trade pioneers and southern producers. The latter are dissatisfied with the way the northerners have maintained control and undermined the original Fair Trade impulses; they are demanding increased roles in governance and capturing more value-adding beyond production.

Consider the complexity: four major commodity systems-coffee, cacao, tea, and bananas, three storable but the fourth fresh; selling in some 20 countries each with national Fair Trade organizations, a Fair Trade Labelling Organizations International (FLO) and its subsidiary Labelling Initiatives, as one governing body, and a second governing body, the International Fair Trade Association (IFAT). FLO represents the northern controlling body, IFAT sides with southern producers, who number in the hundreds of thousands organized in hundreds of cooperatives. Some accommodation has begun to southern producers but the organizational format of Fair Trade is still in contention.

The Huchens book tells a crucial story of how alternative agrifood social movements can achieve success but also move toward conventionalization; and how such moves are resisted. There are lessons to be learned from the Fair Trade experience just as there are different lessons to be learned from the mainstreaming of organics.

Reading this book is no easy matter: there are many organizational actors and readers unfamiliar with Fair Trade will need to continually reference the glossary, prominently available in the front of the book. In addition to the over theorization, Hutchens draws heavily on theorists of power and over-integrates them to the point that the reader is led to believe that the theorists are commenting on Fair Trade when, in fact, they are usually discussing general issues of power.

The book is well referenced and contains a useful index. Hutchens has been generous with organizational diagrams that are mostly helpful. This is not a book for novices but anyone interested in Fair Trade, organizational analysis, and organizational power will find this book useful.

Open Access This article is distributed under the terms of the Creative Commons Attribution Noncommercial License which permits any noncommercial use, distribution, and reproduction in any medium, provided the original author(s) and source are credited. 